\title{
Medicine and Community in Victorian Britain
}

\section{Citation}

Rosenberg, Charles E. 1981. Medicine and community in victorian Britain. Review of Journal of Victorian Social Medicine: The Ideas and Methods of William Farr, by John M. Eyler, and Cholera, Fever and English Medicine, 1825-1865, by Margaret Pelling. Interdisciplinary History 11(4): 677-684.

\section{Published Version}

doi:10.2307/203150

\section{Permanent link}

http://nrs.harvard.edu/urn-3:HUL.InstRepos:4730387

\section{Terms of Use}

This article was downloaded from Harvard University's DASH repository, and is made available under the terms and conditions applicable to Other Posted Material, as set forth at http:// nrs.harvard.edu/urn-3:HUL.InstRepos:dash.current.terms-of-use\#LAA

\section{Share Your Story}

The Harvard community has made this article openly available. Please share how this access benefits you. Submit a story.

\section{Accessibility}


Journal of Interdisciplinary History, XI:4 (Spring I98I), 677-684.

Charles E. Rosenberg

\section{Medicine and Community in Victorian Britain}

Victorian Social Medicine: The Ideas and Methods of William Farr. By John M. Eyler (Baltimore, The Johns Hopkins University Press, I979) 262 pp. \$19.50

Cholera, Fever and English Medicine, 1825-1865. By Margaret Pelling (New York, Oxford University Press, I978) $34^{2}$ pp. \$I8.50

On the whole, medical history has been written by and for physicians. Only in recent years have medicine and science begun to find their way into the canon of "normal history." No survey of early modern Europe could avoid some discussion of the scientific revolution, for example. Nor could any contemporary overview of Victorian England avoid some mention of Edwin Chadwick and sewers, cholera and tenements, and Florence Nightingale and the reform of hospitals.

There has, in fact, been something of a modest explosion of interest in medicine and health (not always, of course, the same thing) in nineteenth-century England. Representing a gradual accretion of interest in medical, administrative, and urban history, it has resulted in an impressive accumulation of biographies and monographs. A kind of orthodoxy has already come into being: the real and contemporaneously perceived deterioration of health in nineteenth-century England was a consequence of urbanization and industrialization; the great wens of Liverpool, Leeds, Manchester, and London were charnel houses for the new urban proletariat and a hazard to anyone who lived in them. A desire for public health reform was a natural consequence. The motivations were varied but in some ways consistent: Christian humanitarianism, a desire to rationalize the new social and economic order, and àn almost visceral revulsion to the filth and crowding which seemed inevitably to foster disease and death. The bureaucratic ordering and control of sewers, factories, and tenements was a

Charles E. Rosenberg is Professor History at the University of Pennsylvania.

0022-1953/8I/020677-8 \$02.50/0

(C) I $98 \mathrm{I}$ by The Massachusetts Institute of Technology and the editors of The Journal of Interdisciplinary History. 
natural response, one justified by a body of medical theory imprecise yet usefully organized around an emphasis on the environmental roots of sickness. Empirical and especially statistical arguments provided a style of discourse which at once legitimated and articulated reformist goals. ${ }^{1}$

Within this growing body of exposition and interpretation, both Eyler's and Pelling's recent studies point to a novel yet not inconsistent emphasis. Both demonstrate how contemporaries used their limited tools of analysis to produce plausible frameworks of explanation immediately useful in responding to stressful social realities and ultimately valuable as guides to further investigation. Most significantly, both underline the complex interpenetration between the world of thought and the world of professional careers and institutions. They trace a shift not only in the content of medical ideas but in the increasing sequestration of such ideas by an ever more self-conscious medical community. Both authors take the ideas of their protagonists seriously. They do not dismiss them as embarrassingly repetitious excuses for ignorance-as some older medically oriented historians did-or as primarily justifications for environmental reform-as some social historians instinctively do-but as serious attempts to find answers for intrinsically difficult questions.

William Farr (I807-I883) exemplifies with particular clarity these linked changes. Farr, a youthful provincial physician, was hired as a compiler of abstracts by the General Register Office in I 839; he was soon promoted to the superintendentship of its statistical department, a position he held until I880. During these four decades Farr's name became almost synonymous in medical circles with the statistical work of the General Register Office. Farr helped create within the register office a set of procedures and

I Among the more important biographies and monographs relevant to the questions raised here are Erwin H. Ackerknecht, "Anticontagionism between I82 I and I867," Bulletin of the History of Medicine, XXII (1948), 562-593; S. E. Finer, The Life and Times of Sir Edwin Chadwick (London, I952); Royston Lambert, Sir John Simon and English Social Administration (London, I963); Philip Abrams, The Origins of British Sociology: 1834-1914 (Chicago, 1968); M. J. Cullen, The Statistical Movement in Early Victorian Britain: The Foundations of Empirical Social Research (New York, i975); F. N. L. Poynter (ed.), Medicine and Science in the 1860s: Proceedings of the Sixth British Congress on the History of Medicine (London, I968); M. Jeanne Peterson, The Medical Profession in Mid-Victorian London (Berkeley, 1978); R. J. Morris, Cholera, 1832: The Social Response to an Epidemic (New York, 1975); M. W. Flinn, "Introduction," in Edwin Chadwick (ed. Flinn), Report on the Santary Condition of the Labouring Population of Gt. Britain, 1842 (Edinburgh, 1965), I-73. 


\section{\begin{tabular}{l|l} 
VICTORIAN MEDICINE & $\mathbf{6 7 9}$
\end{tabular}}

results which allowed him to articulate an improving gospel of hygienic and administrative truth. Although best known for his work with vital statistics, Farr was more a maker of social policy than an innovative statistician; his mathematical sophistication was, in fact, inferior to that of many of his contemporaries. But such failings must have seemed far less significant than the opportunity to don the scientist's garb and in it to intone the moral philosopher's truths. "And what are figures worth," he wrote in I 864, "if they do no good to men's bodies or souls" (I97). Farr's efforts were diffused across a wide range of social problems, though his central concerns always lay in the connections between health and environment. It was only natural that he should have been interested in life and health insurance for workers, just as he was concerned with drainage and housing density and appropriate schemes for categorizing and reporting disease and death.

Statistics was primarily a weapon, only secondarily a body of techniques and data. It is no accident that some of Farr's most striking formulations were based on contrasting death rates between a group of so-called healthy districts and other-less healthy and frequently urban-registration districts. The moral lay in the gap between the life span attainable in appropriate environmental circumstances and those in which most Englishmen lived, sickened, and died. In Farr's hands, statistics served as a kind of metaphorical scheme, scientific in form yet ultimately structured about instructive moral contrasts-between city and country, disease and health, filth and cleanliness, culpable irresponsibility and social responsibility, between the is and the ought to be. ${ }^{2}$ Thus, Farr could call a life table a "biometer" and compare mortality rates to thermometer readings. Consistently enough, Farr pioneered in the use of charts and tables to present the results that he sought to underline; the charts themselves were iconographic renderings of the metaphors implicit in Farr's formal prose. Most importantly, Farr helped create a mathematical and seemingly value-neutral language with which to study disease and thus a language in which to describe-and judge-society. It is only natural that Eyler should have titled one of his chapters "Statistics a Science of Social Reform" or cite approvingly the

2 I have elaborated this argument at somewhat greater length in Rosenberg, "Florence Nightingale on Contagion: The Hospital as Moral Universe," in idem (ed.), Healing and History: Essays for George Rosen (New York, I979), I16-I36. 
argument that Farr's limitations as mathematician may only have aided him in his social manipulations of statistical data.

Nevertheless, Eyler emphasizes that Farr-unlike better known sanitary reformers such as Chadwick and Nightingalealways maintained a close intellectual relationship with the English medical community; he was alert to its changing intellectual currents and responded to them throughout his life. In an illuminating chapter centering on the relationship between Farr and Nightingale (the two had a long and at times close intellectual and political alliance) Eyler emphasizes the contrasts between these two advocates and popularizers of vital statistics. Nightingale and Farr differed sharply in the constituencies they addressed, and they represented very different orientations toward knowledge and the community of its accumulators and disseminators. To the messianic gentlewoman, statistics was a language of social revelation; to Farr it was that, but also a set of procedures which had to be seen in relation to a particular community of actuaries and medical men. If this community clearly rejected particular results or techniques, they would ultimately be found wanting no matter what their social utility. It is not surprising, as Eyler argues, that Farr should have gradually changed his mind as he responded to a changing epidemiological consensus among medical men; it is equally to have been expected that Nightingale would not have altered her mid-century convictions. Although she lived until I89I, she was never to accept the germ theory and always regarded it as a discouragement to environmental reform.

Nowhere did conflict in regard to medical thought and the social role of physicians loom larger than in the explanation of epidemic disease, historically an emotion-filled and socially resonant area and, in mid-Victorian England, a particularly vexed and elusive one. Pelling's monograph is a meticulously detailed reading of that debate. A more appropriate title might have been "The Roots of the Germ Theory: Medical Thought from Metaphor to Microscope." For Pelling has carefully documented a gradual shift in prevailing speculative models between the I820s and I860sconcluding just prior to Joseph Lister's writings on antiseptic surgery in the mid-I860s. It is a period in which modes of etiological explanation shifted from the manipulation of metaphor and analogy (at the beginning of this period especially the metaphors of fermentation and putrefaction and the analogical use of 
smallpox as prototypical contagious disease) to the laboratory study of particular etiological agents and the conditions of their transmission. It is a period, coincidentally, which overlaps with much of the creative life of Farr, as well, a man born in a decade when epidemiological thought was little different from its ancient predecessors and who died at a time when staining, Petri dishes, and microscopes had made bacteriology into the most exciting of the biomedical disciplines.

To argue that epidemiological thought in the first half of the nineteenth century largely consisted of the manipulation of metaphor and analogy is not to make a pejorative judgment; for no more precise tools existed. The metaphors chosen did incorporate sensory evidence-smells, the filth and crowding of Victorian cities, and the everyday experiences of watching bread rise or wine ferment. All of them seemed to explain the way in which untoward environmental circumstances could produce sickness and death. Fermentation was presumed to explain the (unexamined) primary role of the atmosphere in spreading disease; it provided a seemingly circumstantial and scientific content for older views which assumed the miasmatic nature of epidemics. Smallpox provided the fundamental experiential base for that assumedly smaller class of exclusively contagious ailments. Insofar as an illness could be shown to share characteristics with smallpox, it might be presumed contagious; if not, not. By midcentury, however (as Pelling emphasizes), most prudent English physicians found elements of both contagionist and noncontagionist models useful in explaining the incidence of epidemic disease.

The unquestioned connection between crowded surroundings, rotting organic material, and poor ventilation seemed to underline the fact that in such circumstances all ills could become "contagious"- that is, transmissible from one individual to another. That the local atmosphere in tenement room or cellar could serve as a medium of infection could hardly be doubted by any physician experienced with such conditions. The endemic fevers and infantile ailments which thrived in Victorian cities were regarded by most physicians as neither absolutely contagious nor noncontagious. Thus the mid-century profession endorsed on the whole a cautious eclecticism, Pelling argues, whereas the Chadwick-dominated General Board of Health intoned an outmoded 
and doctrinaire anticontagionism, which most physicians regarded as not only ill-advised and extreme but as a presumptuous usurpation of the medical profession's authority. This categorical rejection of any hint of contagionism by the Board of Health was, Pelling emphasizes, unnecessary from a practical point of view; contemporary medical opinion never questioned the need for that environmental reform which Chadwick and like-minded reformers justified through their implacable anticontagionism. It is ironic that John Snow and William Budd-in historical retrospect, at least, their generation's most significant epidemiological thinkers for their emphasis on the transmissibility and specificity of cholera and typhoid-were seen by their contemporaries as guilty of what might be called premature reductionism, of commitment to unproven and unnecessarily narrow models of disease transmission in their relentless use of the fermentation and smallpox analogies. It is only in the light of later knowledge that they appear free of arbitrariness in rejecting the cautious and holistic models of their contemporaries.

By the I860s the eclectic epidemiological consensus of midcentury had already begun to shift. Some physicians had begun to become more specific in their invocation of the fermentation model, seeing the "ferment" as both biological and specific. Louis Pasteur's emphasis on the biological nature and specificity of ferments had begun to replace Justus von Liebig's earlier-and at mid-century excessively fashionable-emphasis on fermentation as chemical process and, by extension, on epidemic disease as an outcome of such processes. At least an influential minority of medical men soon apprehended how relevant this new model of specific biological action might be in explaining disease. Eyler, for example, notes that Farr's epidemiological ideas began to incorporate elements of the Pasteurean model in the I860s-although Lister's enunciation of his antiseptic surgical principles provides a much better known example of such thinking. In most medical minds older ideas about the role of the atmosphere in disease causation, of the danger of any accumulated filth, and of a multidimensional and non-specific view of disease remained tenaciously in place. Change in medical thought was a slow, complex, and ambiguous process.

Even if one is not particularly interested in the maze of diffuse and imprecise ideas which characterized mid-nineteenth-century 
medical thought, both of the books under review point to conclusions of far more general significance. First, the middle third of the nineteenth century saw a marked shift from modes of discourse available to any educated man to more self-consciously specialized-i.e., "professional"-styles and from metaphor and rationalistic argument to a search for mechanism (even if that search was often inspired by the creative use of metaphor). Second, there are extremely instructive parallels between the content of these ideas and the social forms and institutions which produced them. Knowledge has to be seen in terms of community and specific vocation-not simply in its ability to correspond to aspects of the natural world. It is no accident that medical ideas and arguments should have been employed by a spectrum of Victorians as varied as Chadwick, Nightingale, and Farr-not to mention the host of actuaries and medical men unknown to the general historians who devoted their lives to the pursuit of "dry technical" problems and eschewed the marketplace of social policy and reform. It is no accident that this varied spectrum of career and commitment should have existed at mid-nineteenth century, nor that the place of the individual on that spectrum should have turned about their orientation to the medical profession itself. The gradual divergence between Farr and Nightingale is not simply idiosyncratic but rather emblematic of a far more general shift to the isolation of scientific discourse along the lines of professional and bureaucratic training and prerogative. Insofar as Farr, for example, was a member of that professional community his ideas almost inevitably had to change.

Innovation was a central element in this configuration of medical ideas and careers. The lives of Farr, Budd, and Snow, in fact, neatly illustrate the way in which innovation could serve in mid-Victorian England as vocational venture capital for young men lacking in wealth or elite social connection; it was a means to the achievement of a professional reputation and ultimately a rewarding private practice. Thus innovation was built not only into the system of medical values and rewards but into the developmental pattern of the Victorian medical career. It is not that Snow or Budd were simply intellectual freebooters-bounders in search of a quick reputation-but that the nature of mid-century medical careers provided a stage early in life during which clinical and professional repute could be attained in those quiet (and 
hungry) years before a busy practice and demanding hospital connections made such research a luxury. In this sense Snow and Budd were far more modern than a Nightingale or Chadwick, for the meaning of their epidemiological ideas had to be seen not simply in terms of their social efficacy or logical consistency but in terms of their reception and evaluation by a particular medical community.

Nevertheless, such social criteria should not be used to blur the real difference between ideas and their consequent social effects. Knowledge may be provisional, but it is not arbitrary. Although it may seem whiggish and retrograde to emphasize this point, it must be understood that some ideas do approximate nature better than others-and thus provide different options for social policy. We must not underestimate the role of systematic cognitive activity in the making of nineteenth- and twentiethcentury society simply because we disapprove of some of its contemporary consequences. Knowledge does not dictate the social forms of its use but can create the possibility of such social use. Sanitary reform without a knowledge of the germ theory and the techniques of bacteriology was an inherently limited enterprise; cleanliness in surgery without an understanding of the role of bacteria in surgical sepsis was an even more illusory end. (A recent student of cholera in England suggests, interestingly, that the sanitary reforms of the I840s may well have served to increase London's cholera rates; for the city's mid-century mortality was much higher than that experienced in 1832 . $^{3}$

Both Pelling and Eyler are sympathetic to the medical community and sensitive to its social circumstances; yet both are aware of the need to understand text as well as context. Indeed, both make clear that an understanding of technical writings can provide insight into the structure of the social and scientific communities in which they are elaborated-in this case, cognitive road maps to the geography of mid-nineteenth-century English society and especially the role of the medical profession in relation to that community. They remind us that social history must find a place for the articulate as well as the inarticulate in its everbroadening canon. 